\title{
Influence of microfractures and porosity on the physico-mechanical properties and weathering of ornamental granites
}

\author{
Luís M.O. Sousa ${ }^{\mathrm{a}, *}$, Luis M. Suárez del Río ${ }^{\mathrm{b}, 1}$, Lope Calleja ${ }^{\mathrm{b}}$, \\ Vicente G. Ruiz de Argandoña $^{\mathrm{b}}$, Angel Rodríguez Rey \\ ${ }^{a}$ Department of Geology, Universidade de Trás-os-Montes e Alto Douro, Apartado 1013, 5000-911 Vila Real, Portugal \\ ${ }^{\mathrm{b}}$ Department of Geology, Universidad de Oviedo, c/ Arias Velasco, s/n, 33005 Oviedo, Spain
}

Received 10 November 2003; received in revised form 15 September 2004; accepted 1 October 2004

Available online 10 November 2004

\begin{abstract}
The purpose of this paper is to demonstrate the influence porosity and fissuration exert on the physico-mechanical properties and durability of nine Portuguese ornamental granites with different petrographical and physical characteristics. Scanning electron microscopy (SEM) allows the type of cracks (intergranular, intragranular and transgranular) to be identified. A microfracture index was calculated based on the collected data. This index is called linear crack density (LCD) and is defined by the number of cracks per length unit. The results reveal that intragranular cracks are the most frequent and represent between $62.9 \%$ and $82.3 \%$ of all the cracks observed. A physical weathering classification system based on linear crack density values of the studied granites is presented. The voids included in these types of rocks are predominantly microfractures and correlate closely with open porosity and linear crack density. Uniaxial compressive strength and P-wave velocity $\left(V_{\mathrm{P}}\right)$ appear to decrease as linear crack density increases, albeit with low correlation coefficients. This may be due to the fact that linear crack density does not take into account possible preferential crack orientation and both properties are strongly dependent on this preferential orientation. Other textural characteristics, such as grain size and preferential orientation of certain minerals, may contribute to these low correlation coefficients. In ageing tests, the salt crystallization test demonstrated greater material loss in granites with higher linear crack densities and thermal shock testing proved that thermal cracks have a greater influence on $V_{\mathrm{P}}$ in rocks with lower linear crack densities. In light of the ageing tests results, precaution is recommended when using granites with effective porosities greater than $3 \%$ as dimension stone out-of-doors in polluted continental or marine areas.
\end{abstract}

(C) 2004 Published by Elsevier B.V.

Keywords: Petrophysics; Effective porosity; Microfracture; Uniaxial compressive strength; P-wave velocity; Dimension granites

* Corresponding author. Fax: +351259350480.

E-mail addresses: 1sousa@utad.pt (L.M.O. Sousa),1sdelrio@geol.uniovi.es (L.M. Suárez del Río).

${ }^{1}$ Fax: +34 985103161.

0013-7952/\$ - see front matter (C) 2004 Published by Elsevier B.V.

doi:10.1016/j.enggeo.2004.10.001 


\section{Introduction}

The study of the physical properties of rock materials and their respective petrographic interpretation, on the "intact rock" or "rock matrix" level, are important in many areas of the Earth Sciences. In these petrophysical studies, petrographic components are quantified according to their relative importance: voids (pores and cracks), texture and minerals (Álvarez-Calleja et al., 1993).

The presence of voids in the rock, especially microcracks, affects its physical and mechanical

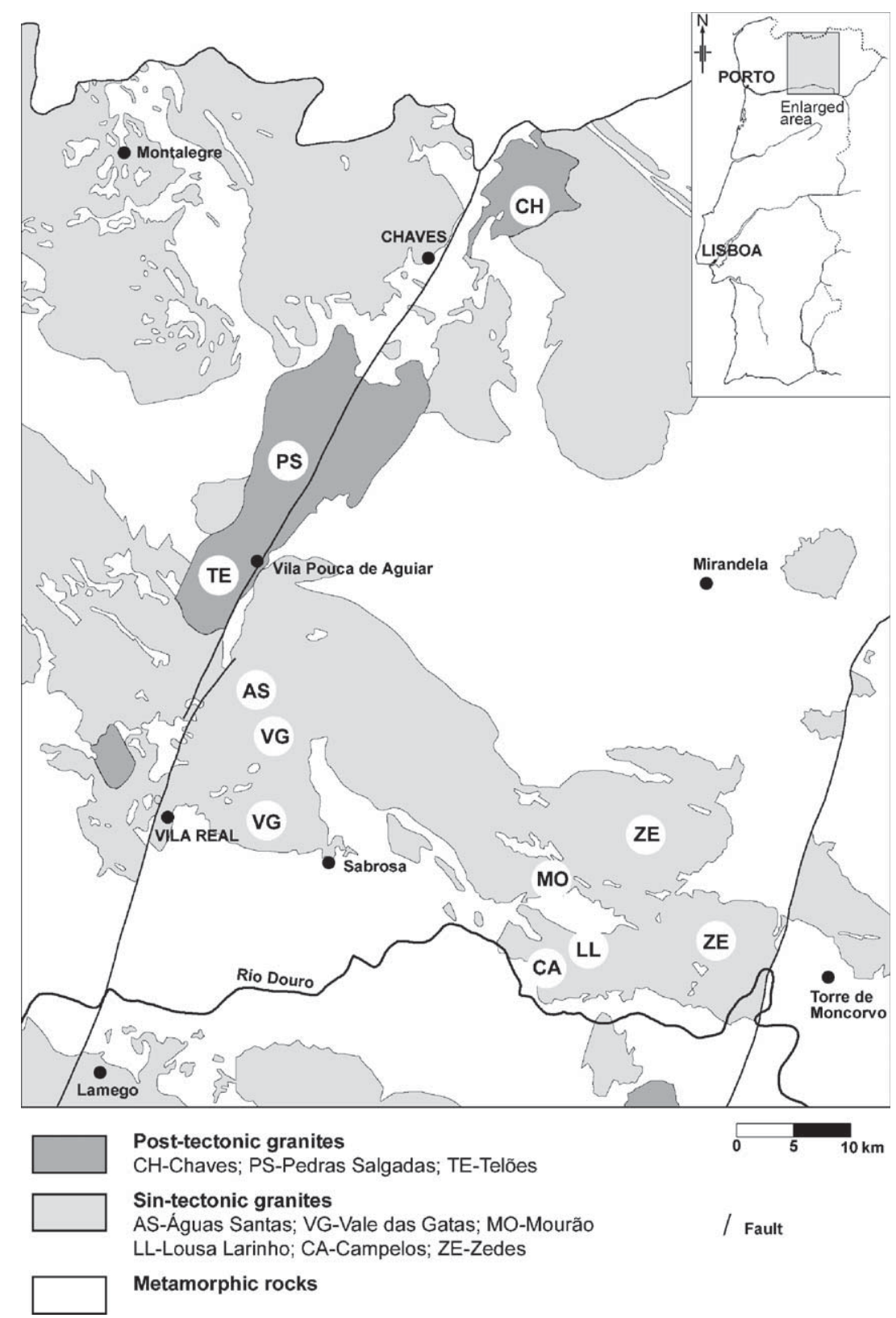

Fig. 1. Location of the granites contemplated in this study (adapted from Serviços Geológicos de Portugal, 1992). 
properties and is responsible for the anisotropy found in many granites (McWilliams, 1966; Engelder and Plumb, 1984; Almeida et al., 1998). Furthermore, for certain studies (e.g., radionuclide migration through the "rock matrix"), the location of the cracks is of the utmost importance, since some minerals are capable of binding certain ions. Cracks can be studied on the basis of the data obtained under both optical and electronic microscopy (Schedl et al., 1986; Montoto et al., 1994).

Mineralogical composition, texture and characteristics of the voids are the main factors involved in controlling the intensity of the physical and chemical damages suffered by rocks (Hudec, 1998) when subjected to new environmental conditions. If we consider that water is the main weathering agent and that open microcracks are the natural way for it to penetrate inside the rock, the relevance of understanding microcrack characteristics and the physical properties related to them (e.g., effective porosity) becomes clear. Rocks undergo measurable weathering as a result of environmental conditions (Halsey et al., 1998), although it is more difficult to observe in low porosity granites. The objective of ageing tests is to reproduce the slow, natural processes of weathering at a more accelerated pace in the laboratory (Dearman, 1982; Martin et al., 1992; Aslam, 1992; Grossi et al., 1997; Rivas et al., 1998; Park et al., 1998).

The physico-mechanical properties of the rocks are essential when assessing their suitability for use as dimension stone, as well as their durability. These data provide appropriate conclusions regarding the proper use of different materials: tiled floors, indoor or outdoor cladding, etc. In this study, we have measured some of the properties of several Portuguese granites used as dimension stones or having the potential for this type of use. The quantification of microfractures in the ornamental granites under study has served as the basis upon which to evaluate the impact of natural microcracks on physico-mechanical properties, as well as on their resistance to certain weathering agents (salt crystallization and thermal shock).

\section{Granites under study}

The granites evaluated in this study are located in the NE of Portugal and belong to two different types: post-tectonic and sin-tectonic granites of the third phase of Hercynian orogeny (Fig. 1). These granites are rocks with a medium to coarse grain size and some of them have a porphyritic texture (Sousa, 2000) (Table 1).

Modal analysis of the granites has been performed using the point counter, following the methodology commonly used in petrological studies that is widely described in the literature, for example in Roubault (1963). Table 2 presents the results of the modal analysis of all these granites. Biotite is more abundant than muscovite in the Chaves, Pedras Salgadas and

Table 1

General petrographical characteristics of the granites studied

\begin{tabular}{|c|c|c|c|c|}
\hline Name & Grain size & Texture & Petrological classification (Streckeisen, 1976) & Type \\
\hline Chaves $(\mathrm{CH})$ & Coarse & $\begin{array}{l}\text { Porphyritic tendency, } \\
\text { hypidiomorphic granular }\end{array}$ & Biotitic monzogranite & Biotitic \\
\hline Pedras Salgadas (PS) & Medium to coarse & $\begin{array}{l}\text { Slight porphyritic tendency, } \\
\text { hypidiomorphic granular }\end{array}$ & Biotitic monzogranite & Biotitic \\
\hline Telões (TE) & Coarse & $\begin{array}{l}\text { Slight porphyritic tendency, } \\
\text { hypidiomorphic granular }\end{array}$ & Biotitic granodiorite & Biotitic \\
\hline Águas Santas (AS) & Medium to coarse & Hypidiomorphic granular & Two micas monzogranite & Muscovitic-biotitic \\
\hline Vale das Gatas (VG) & Medium to coarse & $\begin{array}{l}\text { Slight porphyritic tendency, } \\
\text { hypidiomorphic granular }\end{array}$ & Two micas monzogranite & Muscovitic-biotitic \\
\hline Mourão (MO) & Medium & Hypidiomorphic granular & Two micas monzogranite & Muscovitic-biotitic \\
\hline Lousa-Larinho (LL) & Medium & Hypidiomorphic granular & Two micas monzogranite & Muscovitic-biotitic \\
\hline Campelos (CA) & Medium to coarse & $\begin{array}{l}\text { Slight porphyritic tendency, } \\
\text { hypidiomorphic granular }\end{array}$ & Two micas monzogranite & Muscovitic-biotitic \\
\hline Zedes (ZE) & Medium to coarse & $\begin{array}{l}\text { Porphyritic tendency, } \\
\text { hypidiomorphic granular }\end{array}$ & Two micas monzogranite & Muscovitic-biotitic \\
\hline
\end{tabular}


Table 2

Modal composition of the granites under study (abbreviations can be found in Table 1)

\begin{tabular}{|c|c|c|c|c|c|c|c|c|c|}
\hline \multirow[t]{2}{*}{ Mineral } & \multicolumn{9}{|c|}{ Granite } \\
\hline & $\mathrm{CH}$ & PS & $\mathrm{TE}$ & AS & VG & MO & LL & $\mathrm{CA}$ & $\mathrm{ZE}$ \\
\hline Quartz & 32.5 & 33.4 & 27.8 & 35.8 & 33.0 & 33.6 & 31.8 & 31.6 & 33.6 \\
\hline Potassium feldspar & 29.0 & 28.4 & 20.0 & 23.6 & 27.3 & 24.3 & 26.4 & 27.0 & 25.9 \\
\hline Plagioclase & 30.2 & 33.2 & 41.7 & 29.3 & 24.4 & 27.7 & 27.8 & 25.0 & 27.5 \\
\hline Biotite & 8.2 & 4.3 & 10.5 & 3.3 & 5.4 & 4.8 & 3.8 & 4.8 & 3.5 \\
\hline Muscovite & 0.1 & 0.7 & & 7.9 & 9.5 & 9.3 & 9.8 & 11.1 & 9.2 \\
\hline Apatite & & & & 0.1 & 0.3 & 0.2 & 0.1 & 0.1 & 0.1 \\
\hline Chlorite & & & & & & 0.1 & & & \\
\hline Tourmaline & & & & & & & & 0.3 & \\
\hline Others & & & & & 0.1 & & 0.3 & 0.1 & 0.2 \\
\hline
\end{tabular}

Telões granites; all other granites have a slightly higher proportion of muscovite versus biotite.

\section{Microfracture analysis}

Several microscopic techniques exist that are useful in crack studies: optical petrographics, fluorescence, laser confocal and scanning electron microscopy (SEM). Optical petrographic microscopy is not the optimal technique in these cases, since some of the cracks are very difficult to detect, particularly those located between minerals (intergranular cracks). Even intragranular (cracks inside a mineral) and transgranular (affecting more than one mineral) cracks can be difficult to observe when not highlighted by iron oxides or other filling minerals (Fig. 2). A combination of both optical petrographic and fluorescence microscopy (after filling the cracks with a fluorescent dye, such as rhodamine B dissolved in resin) can overcome this problem (Montoto et al., 1987), but it is a complex, time-consuming procedure that hinders quantification of crack density and characteristics. Laser confocal microscopy is a rather useful procedure since it permits a $3 \mathrm{D}$-reconstruction of the crack network, but it must be combined with optical petrographic microscopy in order to study the crack location with respect to the minerals. Nonetheless, this technique has not frequently been used in rock studies.

For these reasons, linear crack density (LCD; defined as the number of cracks per millimeter) has been calculated by counting the number of cracks in several scanning lines with a total length of $50 \mathrm{~mm}$ using a scanning electron microscope. Surfaces for study were obtained after polishing granite slabs sawed with a low deformation, low speed diamond blade saw (Isomet) so as to prevent creating morphological artifacts, mainly microfractures.

The characteristics of the cracks were also considered, although the results of intra-, inter- and trans-
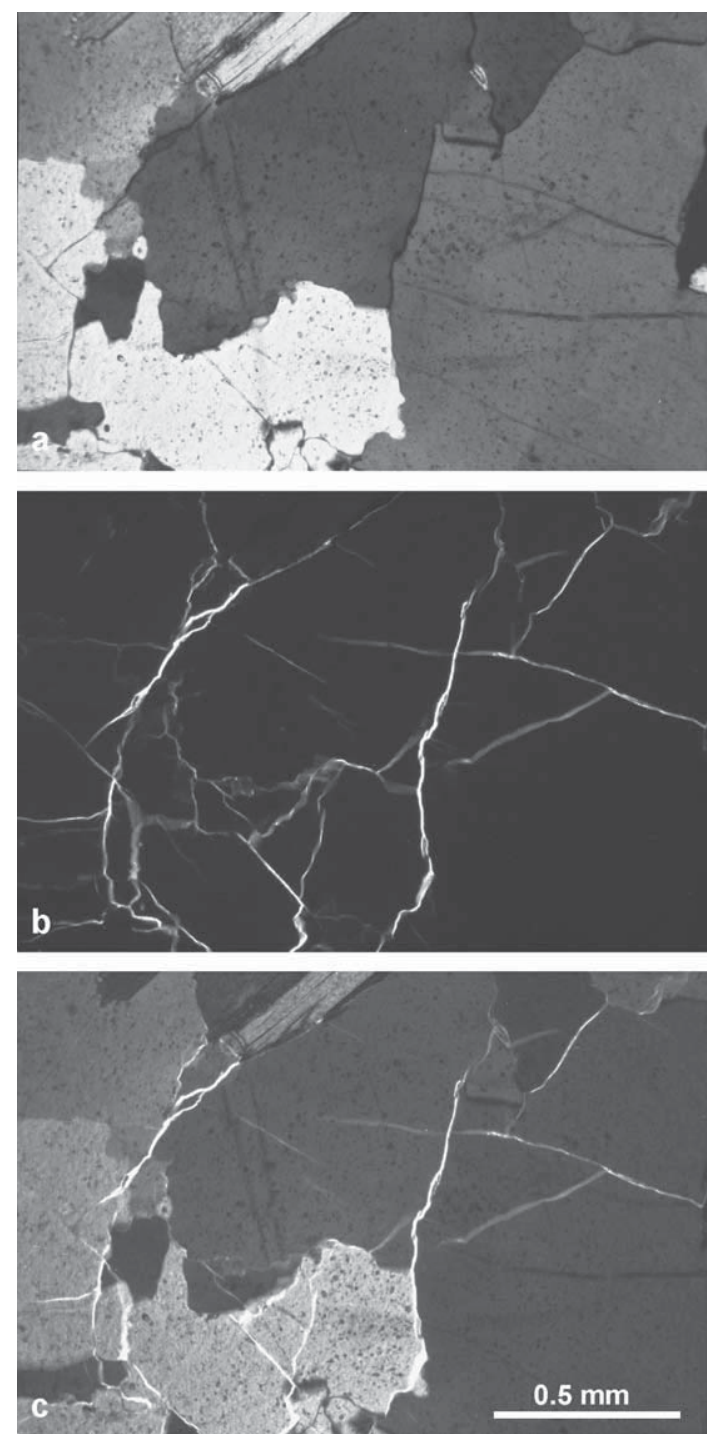

Fig. 2. The same area of a granite as observed (a) under optical polarizing microscopy (cross-polarized light); (b) under fluorescence microscopy, where only the cracks are observed; and (c) under a combination of both microscopy techniques. 


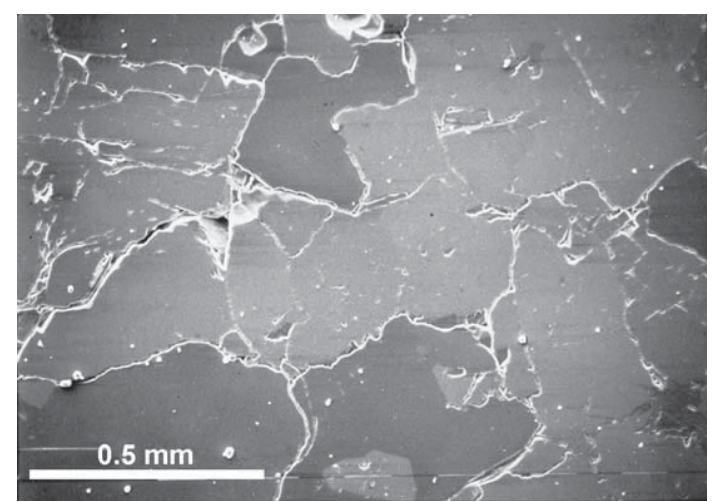

Fig. 3. A granite as observed under scanning electron microscopy.

granular cracks must be interpreted with care given that the magnification used $(\times 400)$ does not always allow us to see if a crack affects more than one mineral. In fact, transgranular cracks have not been quantified, since they can be considered to be a combination of inter- and intragranular cracks (Fig. 3).

Table 3 shows the relative data of the identified cracks. It is clear that intragranular cracks represent the majority of all cracks observed. The incidence of this type of crack ranges from $62.9 \%$ in the Águas Santas granite to $82.3 \%$ in the Pedras Salgadas granite. The intragranular cracks inside feldspars represent more than half of the intragranular cracks detected with the exception of the Águas Santas (37.9\%) and Telões (47.5\%) granites. Álvarez-Calleja et al. (1993) also assessed the preponderance of microfractures in feldspars with respect to the other mineral phases in El Berrocal granite (Toledo, Spain).

Intergranular cracks, representing less than onethird of all microfractures in all the granites, are predominantly located in the quartz-feldspar boundaries, except in the Chaves and Telões granites.

The microfracture data obtained (Table 4) reveal that the granites under study have a linear crack density that varies from $1.4 \mathrm{cracks} / \mathrm{mm}$ in the Telões granite to $5.9 \mathrm{cracks} / \mathrm{mm}$ in the Campelos granite. As expected, the soundest biotitic granites (Chaves and Telões) have the lowest values of LCD, since the presence of cracks tends to be a key factor in increasing the weathering rate, at least in the presence of water (in any state). Lousa-Larinho (4.8 cracks/ $\mathrm{mm}$ ) and Campelos (5.9 cracks $/ \mathrm{mm})$ granites have the highest values, despite the fact that the Águas Santas granite is the most weathered of all those studied.

In papers dealing with the weathering of granitic rocks, various classifications have been proposed. The most common classifications are based on simple geological descriptions (macroscopic observations such as discoloration, staining and mineral alteration) (Clayton and Arnold, 1972; Durgin, 1977; IAEG, 1981; ISRM, 1981a,b; Anonymous, 1995; Gupta and Rao, 1998, 2000; Ehlen, 2002). Lan et al. (2003) reported the following methods for classifying degrees of weathering: (1) a geological descriptionbased method including visual observations, (2) a single index method with a point load test and wave velocity, and (3) a comprehensive method; that is, an integrated quantitative index based on various factors. Weathering indices have been categorized as chemical, mineralogical-petrographical and engineering (Gupta and Rao, 2001). Chemical weathering indices evaluate the chemical processes associated with weathering so as to understand their influence on geotechnical behavior. Several mineralogical and

Table 3

Different crack percentages relative to total microfractures

\begin{tabular}{|c|c|c|c|c|c|}
\hline \multirow[t]{2}{*}{ Granite name } & \multicolumn{3}{|c|}{ Intragranular cracks ( $\%$ of total) } & \multicolumn{2}{|c|}{ Intergranular cracks $(\%$ of total $)$} \\
\hline & All & Feldspars & Quartz & All & Quartz-feldspar \\
\hline Chaves & 69.8 & 65.2 & 0.9 & 30.2 & 7.8 \\
\hline Pedras Salgadas & 82.3 & 64.2 & 18.1 & 17.7 & 12.8 \\
\hline Telões & 78.8 & 47.5 & 27.5 & 21.2 & 7.5 \\
\hline Águas Santas & 62.9 & 37.9 & 20.3 & 37.1 & 20.7 \\
\hline Vale das Gatas & 66.9 & 54.9 & 11.4 & 33.1 & 28.6 \\
\hline Mourão & 71.9 & 60.8 & 8.7 & 28.1 & 15.6 \\
\hline Lousa-Larinho & 67.8 & 53.8 & 13.5 & 32.8 & 19.2 \\
\hline Campelos & 75.6 & 51.5 & 18.1 & 24.4 & 12.3 \\
\hline Zedes & 74.0 & 66.7 & 4.0 & 26.0 & 20.3 \\
\hline
\end{tabular}


petrographical parameters can be evaluated in weathering processes. These parameters include the percentage of unsound minerals or secondary minerals and the number of fractures. Engineering-based indices take into account key engineering properties such as water absorption, ultrasonic wave speed, slake durability or unconfined compressive strength.

Irfan and Dearman (1978) proposed a weathering classification known as the Microfracture $\operatorname{Index}\left(I_{\mathrm{f}}\right)$, based on rock microfractures. These authors attributed weathering classes depending upon the Microfracture Index, defined as the number of cracks observed in a $1-\mathrm{cm}$ line under optical petrographical microscopy. This classification is not applicable when observations are performed under scanning electron microscopy. The value thus determined (SEM) is more representative than that obtained under optical microscopy, as previously explained. We therefore propose a new classification based on linear crack density, obtained by means of SEM (Table 5). Thus, the studied granites are classified as sound (TE), slightly weathered (CH), moderately weathered (PS, VG, ZE and MO) and weathered (LL, CA and AS). However, weathering indices based solely on the number of cracks are incapable of providing useful information as to the rock's true microfracture network because crack width and length (as well as orientation) are not accounted for. The use of a microfracture index based on crack area, as proposed by Al-Qudami et al. (1997) may overcome this limitation.

\section{Physico-mechanical properties}

Although other physical properties have been measured, only the values of effective porosity,

Table 4

Fissuration index of the granites under study

\begin{tabular}{ll}
\hline Granite name & Linear crack density $($ cracks $/ \mathrm{mm})$ \\
\hline Chaves & 1.9 \\
Pedras Salgadas & 3.3 \\
Telões & 1.4 \\
Águas Santas & 4.6 \\
Vale das Gatas & 3.0 \\
Mourão & 4.3 \\
Lousa-Larinho & 4.8 \\
Campelos & 5.9 \\
Zedes & 3.1 \\
\hline
\end{tabular}

Table 5

Classes of weathering based on linear crack density and classification of the granites included in this study (abbreviations can be found in Table 1)

\begin{tabular}{llll}
\hline $\begin{array}{l}\text { Rock weathering } \\
\text { class }\end{array}$ & Degree & $\begin{array}{l}\text { Linear crack } \\
\text { density (cracks/mm) }\end{array}$ & Granite name \\
\hline $\begin{array}{l}\text { Sound } \\
\begin{array}{l}\text { Slightly } \\
\text { weathered }\end{array}\end{array}$ & I & $<1.5$ & TE \\
$\begin{array}{l}\text { Moderately } \\
\text { weathered }\end{array}$ & III & $3.0-4.5$ & CH \\
$\begin{array}{l}\text { Weathered } \\
\text { Highly weathered }\end{array}$ & V & $\begin{array}{l}4.5-6.0 \\
\end{array}$ & PS VG, ZE, MO \\
& & & LL, CA, AS
\end{tabular}

uniaxial compressive strength and P-wave velocity are presented. The RILEM (1980) recommendations for test No. I.1 have been followed and cubes measuring $5 \times 5 \times 5 \mathrm{~cm}^{3}$ were used for determining effective porosity. The specimens were placed under vacuum for $24 \mathrm{~h}$; water was then slowly introduced into the vacuum vessel until the specimens were covered. The vacuum was maintained for another $24 \mathrm{~h}$ and, after releasing the vacuum, the specimens remained submerged in water at atmospheric pressure for $24 \mathrm{~h}$.

Uniaxial compressive strength was determined following ISRM $(1981 \mathrm{a}, \mathrm{b})$ suggestions on five cylindrical samples $(49.8 \mathrm{~mm}$ in diameter and $123-125$ $\mathrm{mm}$ in length). The propagation rate of seismic waves was calculated on the basis of determinations performed on six specimens of each rock type identical to those used in the uniaxial compressive strength test, using an ultrasonic NEW SONIC VIEWER, model 5217A from OYO (Japan). The test specimens were obtained from the same block of rock in order to decrease the effect of the naturally occurring variations in the intrinsic characteristics of the granites and so as to compare the values for the various properties in the different granites, thereby allowing a coherent petrophysical interpretation to be made. The physical properties appear in Table 6.

The studied granites have a low degree of porosity, a characteristic that is frequently found in this type of rock in sound conditions. The Águas Santas granite (with the highest porosity: $3.72 \%$ ) is the most weathered one. This can render it unsuitable for use in external claddings, at least in wet or polluted areas and/or in continental or marine climates. Overall, the sound granites present high uniaxial compressive 
Table 6

Mean open porosity $\left(n_{\mathrm{o}}\right)$, uniaxial compressive strength (UCS) and P-wave velocity $\left(V_{\mathrm{P}}\right)$ values

\begin{tabular}{llll}
\hline Granite name & $n_{\mathrm{o}}(\%)$ & UCS $(\mathrm{MPa})$ & $V_{\mathrm{P}}(\mathrm{m} / \mathrm{s})$ \\
\hline Chaves (CH) & 0.76 & 158.5 & 5753 \\
Pedras Salgadas (PS) & 0.94 & 197.0 & 4516 \\
Telões (TE) & 0.64 & 153.0 & 4338 \\
Águas Santas (AS) & 3.72 & 62.4 & 2339 \\
Vale das Gatas (VG) & 0.88 & 107.4 & 3787 \\
Mourão (MO) & 1.00 & 126.2 & 4258 \\
Lousa-Larinho (LL) & 1.00 & 140.1 & 3916 \\
Campelos (CA) & 1.30 & 87.0 & 3700 \\
Zedes (ZE) & 1.00 & 99.3 & 3877 \\
\hline
\end{tabular}

strengths. Pedras Salgadas, with 197.0 MPa, stands out as it is slightly higher than the other sound granites, such as Chaves and Telões. This difference may be attributable to the smaller grain size of the first and to the heterogeneities of the last two (Wong et al., 1996). On the other hand, the Águas Santas granite stands out with a very low value of uniaxial compressive strength $(62.4 \mathrm{MPa})$, due to the high degree of weathering as indicated by the high effective porosity value, which can limit its use in certain conditions.

P-wave velocity results $\left(V_{\mathrm{P}}\right)$ range from $5735 \mathrm{~m} / \mathrm{s}$ (Chaves granite) to $2339 \mathrm{~m} / \mathrm{s}$ (Águas Santas granite). With the exception of the Águas Santas granite, all the others present $V_{\mathrm{P}}$ values greater than $3700 \mathrm{~m} / \mathrm{s}$, which is consistent with the values obtained by several authors for granitic rocks that are not highly weathered (Suárez del Río, 1982; Delgado Rodrigues, 1983; Calleja, 1985; Eze, 1997; Begonha, 1997; Neiva et al., 2000).

\section{Durability tests}

Two durability tests were performed: salt crystallization and thermal shock. In these tests, seven cubic specimens ( $5 \mathrm{~cm}$ edge) of each granite were used in accordance with the proposed RILEM (1980) recommendations. Compressional wave speed was measured in the three orthogonal axes of the cubes using the previously mentioned equipment.

According to the RILEM recommendations (1980), there are three different stages in the salt crystallization test: in the first stage, the samples are immersed into a salt solution; the second is a drying stage, and the third stage consists of cooling. The duration of each stage was established following the recommendations for these tests, as well as on the basis of the suggestions made by Alonso et al. (1987): samples were immersed in a $\mathrm{Na}_{2} \mathrm{SO}_{4} \cdot 10 \mathrm{H}_{2} \mathrm{O} 14 \%$ solution at $20{ }^{\circ} \mathrm{C}$. They were then held in a $60{ }^{\circ} \mathrm{C}$ oven for drying for $16 \mathrm{~h}$, before being cooled at room temperature (20 ${ }^{\circ} \mathrm{C}$ ) for $4 \mathrm{~h}$. Weight variation measurements and surface observations were made after the last stage. At the end of the test, the samples are washed in fresh water to remove all the salt crystals contained inside the specimens. One hundred cycles were performed in this test. An increase in weight of the specimen weight is generally observed during the first 15-20 cycles, as a result of the salt accumulation inside the specimens (Martínez Hernando and Suárez del Río, 1989; Ihalainen and Uusinoka, 1994), followed by a period during which weight loss is observed (Table 7). The Chaves, Pedras Salgadas and Telões granites behave quite similarly, with very low weight losses, whereas the Águas Santas granite presents the most adverse behavior.

The methodology used to conduct the thermal shock test did not follow any established standard and was designed to verify the impact of an abrupt change in temperature on the granites. To do so, the specimens were placed inside a $105{ }^{\circ} \mathrm{C}$ oven for $2 \mathrm{~h}$, after which time they are immersed in water at a temperature of $20{ }^{\circ} \mathrm{C}$. The two stages that were carried out consisted of: immersion-during which time the specimens remained immersed in water for $2 \mathrm{~h}$ (during the test interruptions the samples remained immersed in water); heating - the specimens were

Table 7

Weight variation following the crystallization salt test

\begin{tabular}{lll}
\hline Granite name & \multicolumn{2}{l}{ Weight variation (\%) } \\
\cline { 2 - 3 } & With salts & Washed specimens \\
\hline Chaves & -0.06 & -0.16 \\
Pedras Salgadas & -0.07 & -0.25 \\
Telões & -0.06 & -0.14 \\
A. Santas & -3.14 & -3.74 \\
V. Gatas & -0.15 & -0.29 \\
Mourão & -0.19 & -0.32 \\
Lousa-Larinho & -0.16 & -0.33 \\
Campelos & -0.53 & -0.71 \\
Zedes & -0.40 & -0.54 \\
\hline
\end{tabular}


Table 8

Decrease in $V_{\mathrm{P}}$ during thermal shock testing

\begin{tabular}{lll}
\hline Granite name & \multicolumn{2}{l}{$V_{\mathrm{P}}$ decrease $(\%)$} \\
\cline { 2 - 3 } & Cycle 54 & Cycle 125 \\
\hline Chaves & 10.2 & 10.8 \\
Pedras Salgadas & 12.5 & 12.7 \\
Telões & 12.9 & 14.0 \\
Águas Santas & 5.9 & 8.1 \\
Vale das Gatas & 9.3 & 10.2 \\
Mourão & 10.2 & 12.1 \\
Lousa-Larinho & 9.6 & 11.3 \\
Campelos & 5.1 & 7.2 \\
Zedes & 5.9 & 7.4
\end{tabular}

placed inside a $105{ }^{\circ} \mathrm{C}$ oven for $2 \mathrm{~h}$. A total of 125 cycles were performed at this test. The induced damages were evaluated by surface observations and by the change in P-wave velocity at $24,54,80$ and 125 cycles in dry specimens. Surface damage or losses of material were not observed, with the exception of a slight chromatic darkening due to the heating. In contrast, all the studied granites showed a reduction in $V_{\mathrm{P}}$; this decrease is more pronounced before cycle 54 . The significant decrease in $V_{\mathrm{P}}$ during the initial cycles has to do with the physical alterations in the external portion of the sample, consisting of the development of intergranular cracks (Ruiz de Argandoña et al., 1988; Suzuki et al., 1995) and the increased width of previous intergranular cracks (Suzuki et al., 1998). The second phase, during which $V_{\mathrm{P}}$ values are reduced at a lower rate or may even stabilize, is more closely related to thermal fatigue than to new crack formation. An in-depth analysis of $V_{\mathrm{P}}$ variation allows us to verify that during the first 54 cycles, the highest variation occurs in the least weathered granites ( $\mathrm{CH}, \mathrm{TE}$ and $\mathrm{PS}$ ) and vice versa (Table 8).

\section{The influence of porosity and microfractures on other physical properties}

The relationship between two value sequences can be established by the correlation coefficient $(R)$. The best fit curves for both sequences is obtained by the least-squares method and the fitting quality is given by the determination coefficient $\left(R^{2}\right)$. This value, ranging from 0 to 1 , must be high if the curve is to be representative of the relationship between variables (Davis, 1986).

The significant relationships between obtained properties are indicated in an attempt to reveal the

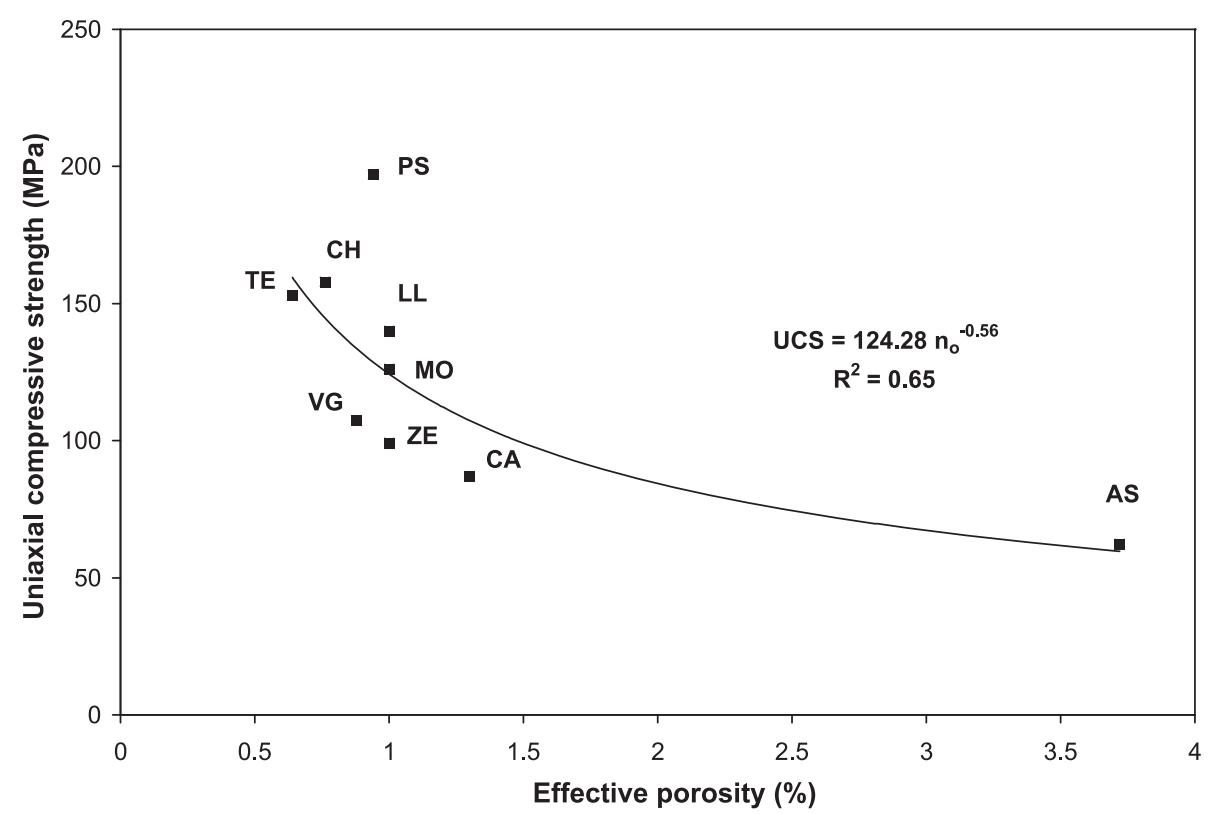

Fig. 4. Relationship between uniaxial compressive strength (UCS) and effective porosity $\left(n_{\mathrm{o}}\right)$ (abbreviations can be found in Table 1). 


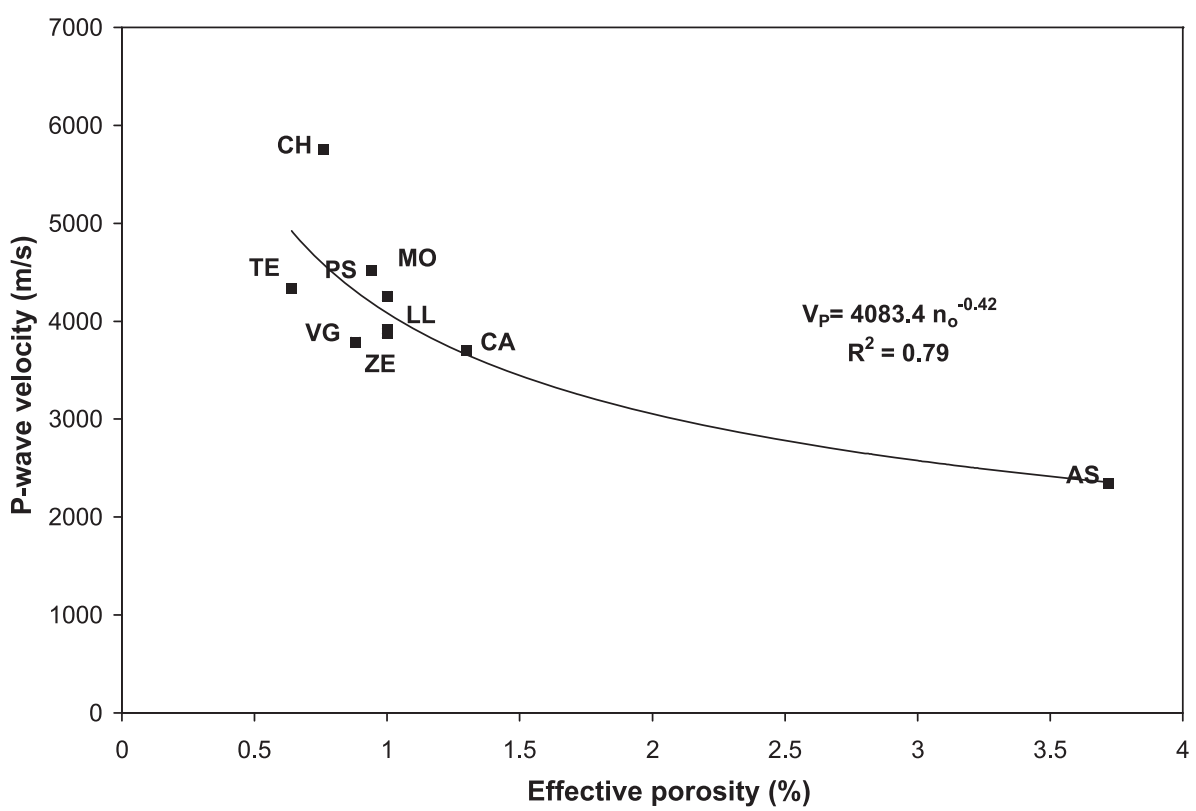

Fig. 5. Relationship between the velocity of compressional waves $\left(V_{\mathrm{P}}\right)$ and effective porosity $\left(n_{\mathrm{o}}\right)$ (abbreviations can be found in Table 1$)$.

influence of porosity in general and of microfractures, in particular. Best fit curves and $R^{2}$ values are only indicative of the relationship between the properties because porosity distribution cannot be accurately represented by means of mathematical equations. When comparing some of the results of the physical properties measured, we can first conclude that uniaxial compressive strength decreases as the porosity increases (Fig. 4), as previously stated by several authors with respect to

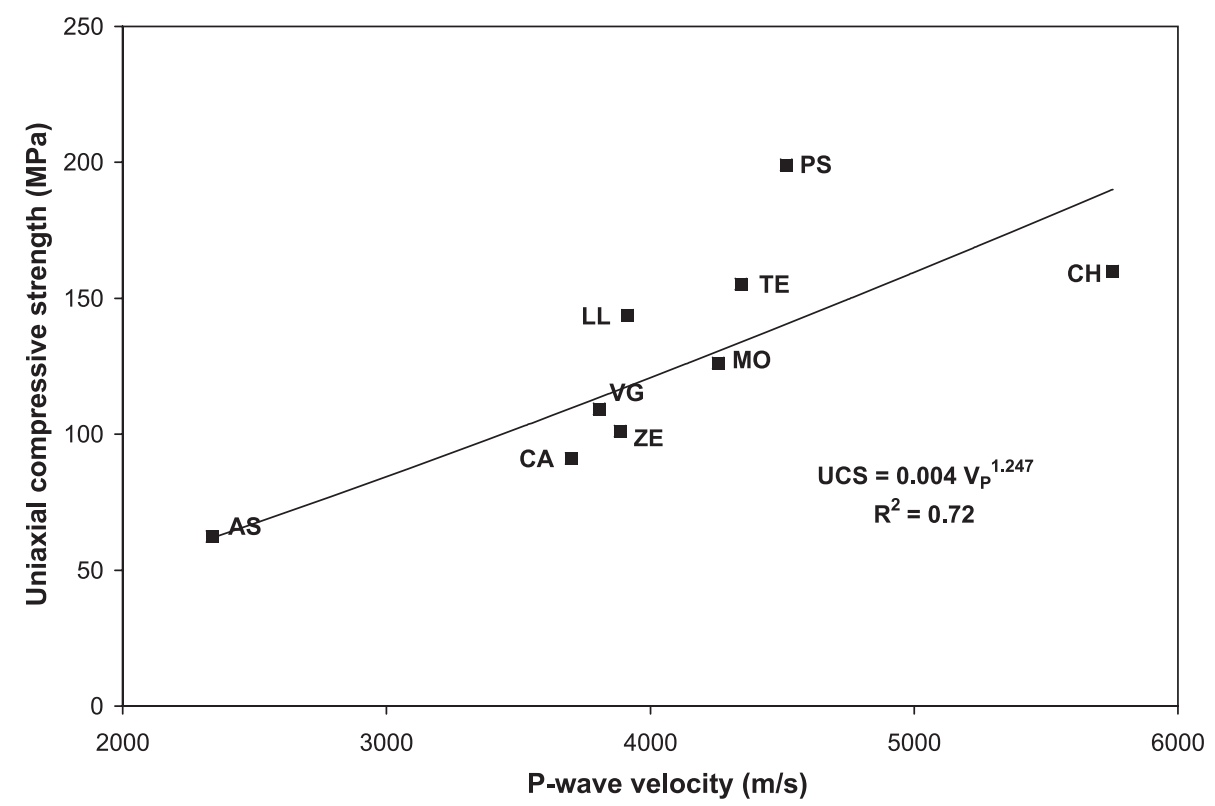

Fig. 6. Relationship between uniaxial compressive strength (UCS) and P-wave velocity $\left(V_{\mathrm{P}}\right)$ (abbreviations can be found in Table 1). 


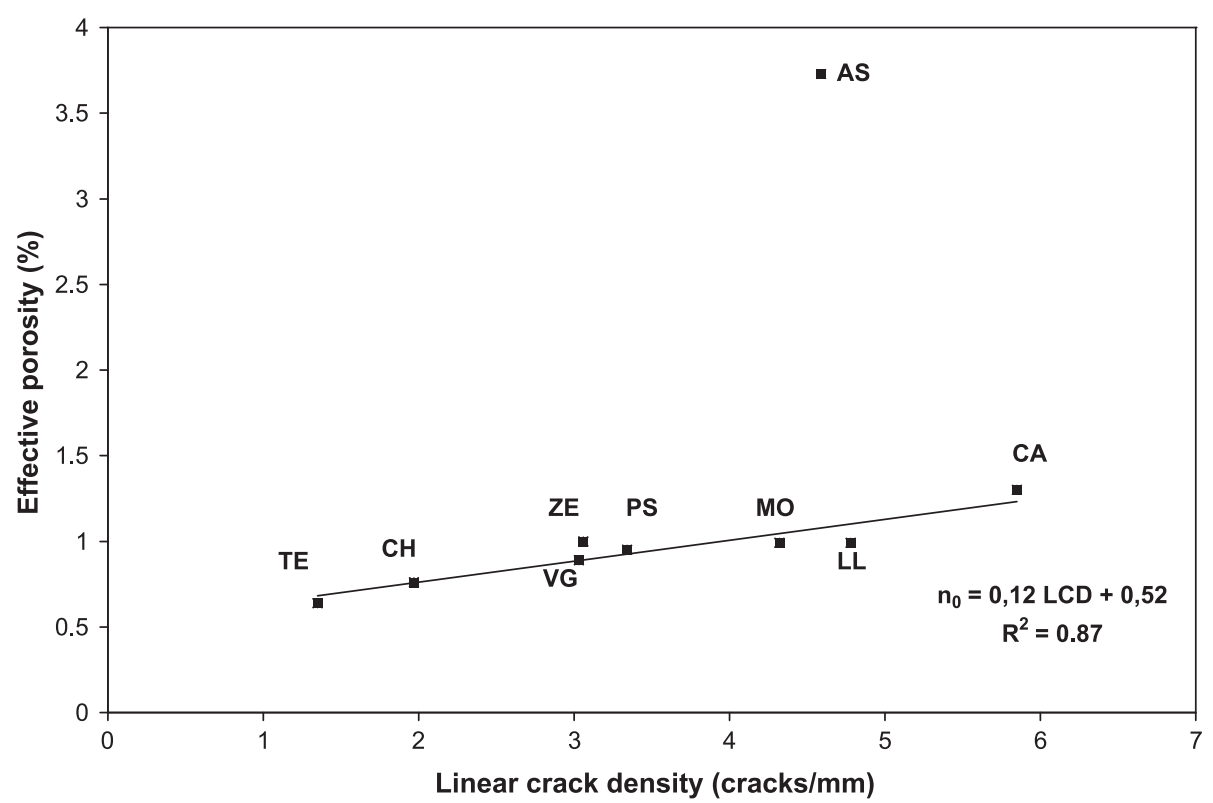

Fig. 7. Relationship between effective porosity $\left(n_{\mathrm{o}}\right)$ and LCD; not including AS granite (abbreviations can be found in Table 1).

granitic rocks (Suárez del Río, 1982; Begonha, 1997; Tugrul and Zarif, 1999). Fig. 5 shows the relationship between $V_{\mathrm{P}}$ and effective porosity in the granites under study, establishing the inverse relationship between both, as has also been pre- viously proven by several authors in different litological types (Calleja et al., 1989; Marques and Vargas, 1998; Jermy and Bell, 1998). As porosity increases, ultrasonic velocity decreases; however, rocks with the same porosity but that have a

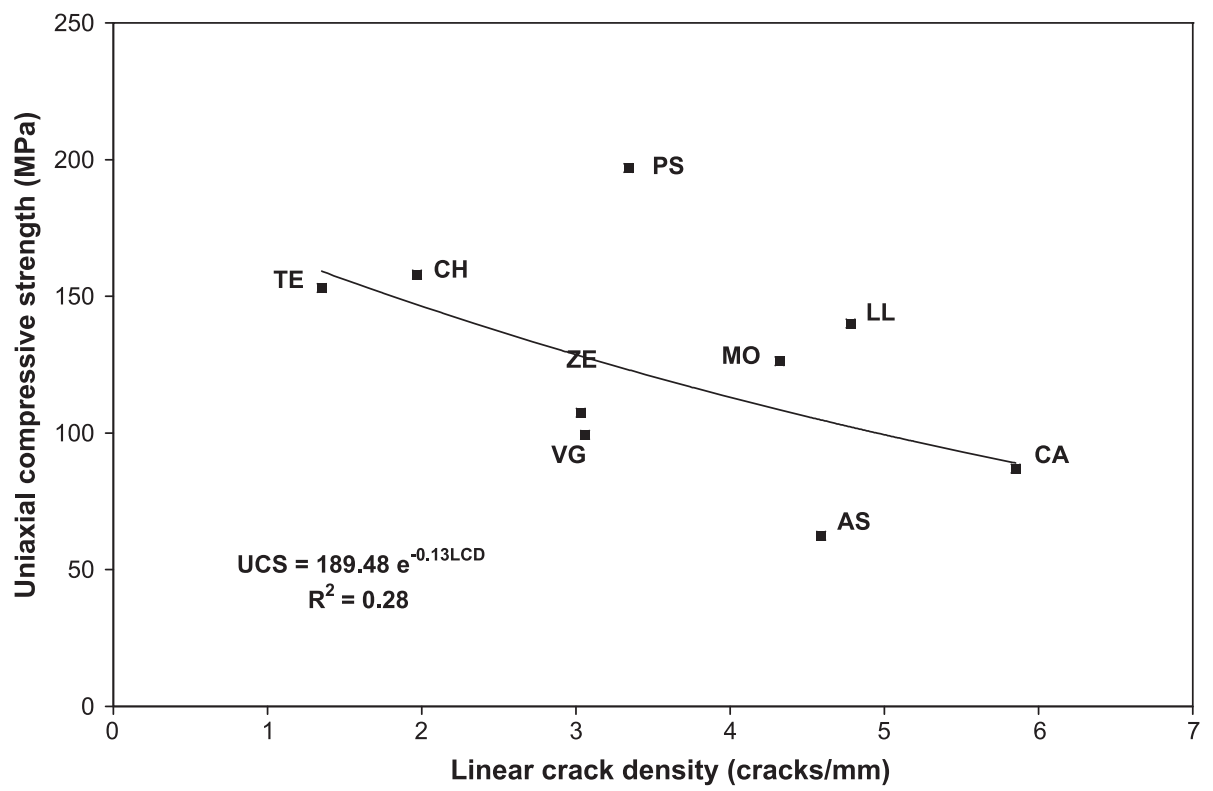

Fig. 8. Relationship between the uniaxial compressive strength (UCS) and the LCD (abbreviations can be found in Table 1). 


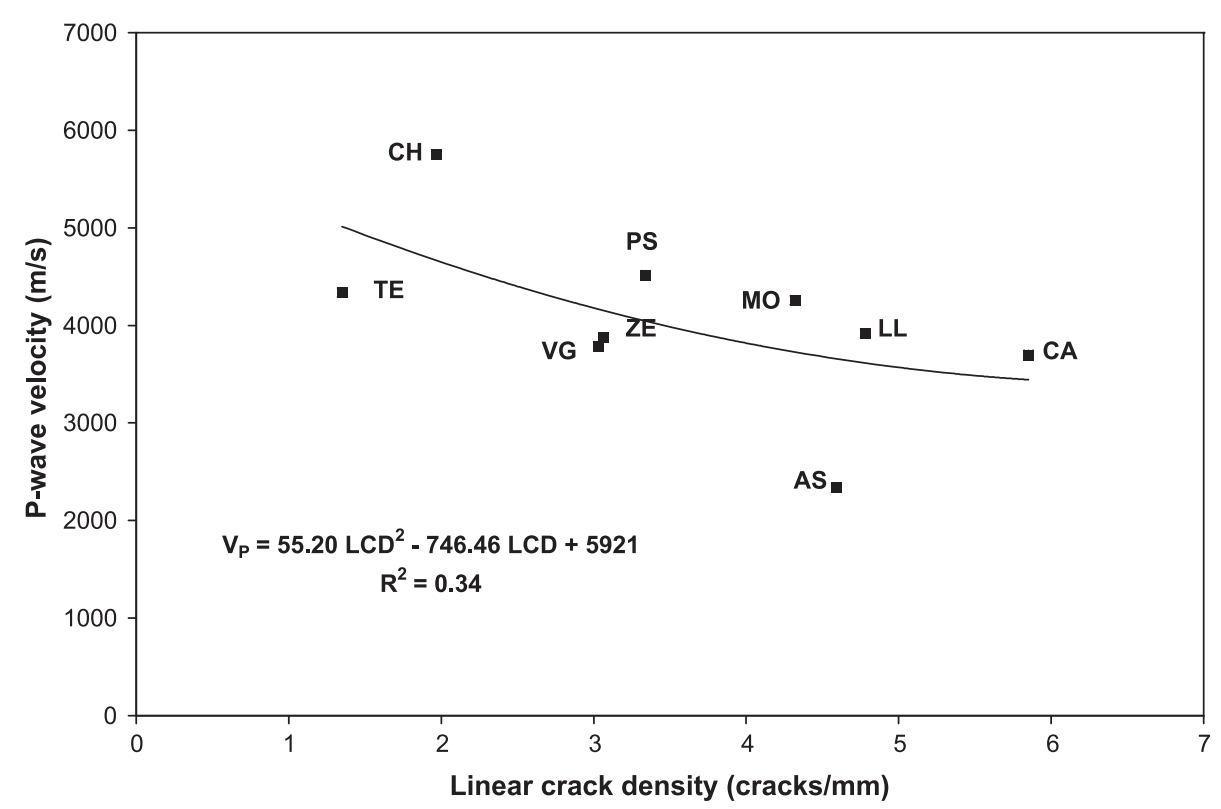

Fig. 9. Relationship between P-wave velocity $\left(V_{\mathrm{P}}\right)$ and LCD (abbreviations can be found in Table 1).

persistent network of microfractures present a propagation velocity that is inferior to that of rocks with a greater prevalence of pores vs. microfractures (Kelsall et al., 1986). The relationship between uniaxial compressive strength and compressional wave velocity appears in Fig. 6. As expected, the lower the uniaxial compressive strength, the lower the P-wave velocity and vice versa. The presence of

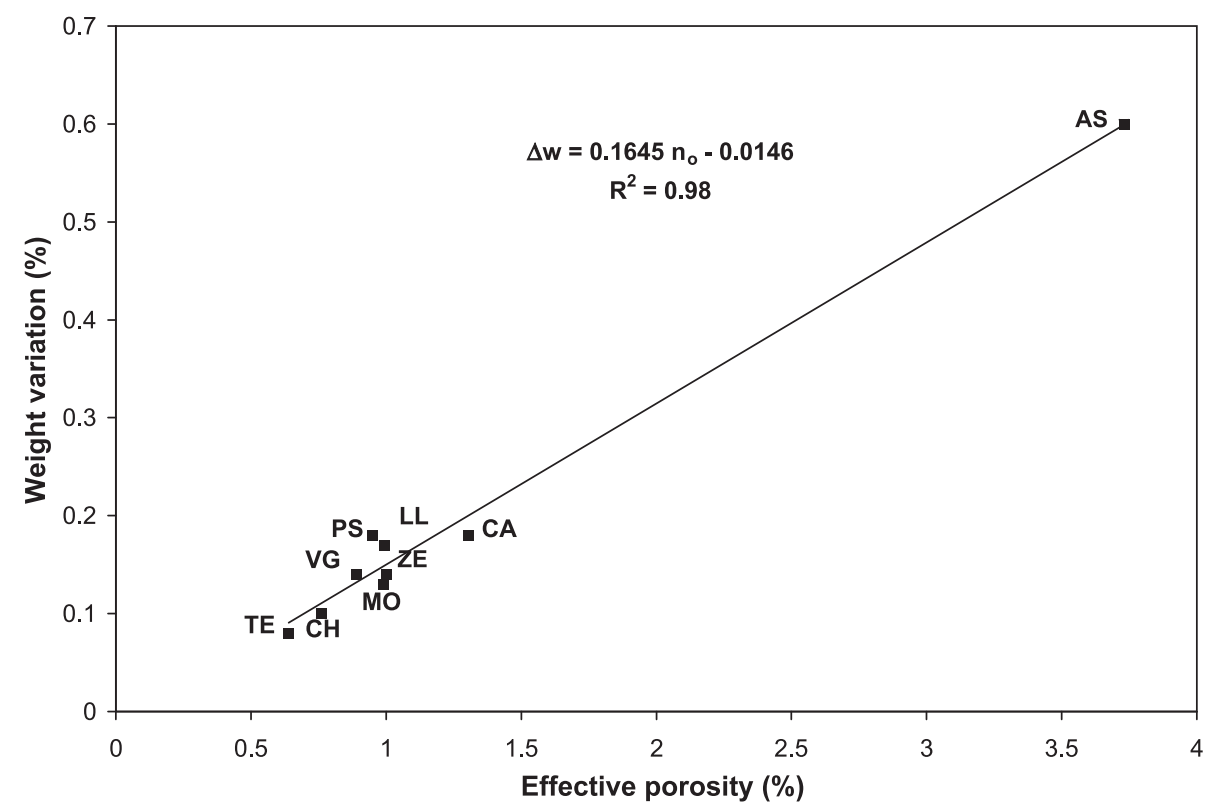

Fig. 10. Relationship between weight difference $(\Delta w)$ in the specimens with and without salt and effective porosity $\left(n_{\mathrm{o}}\right)($ abbreviations can be found in Table 1). 

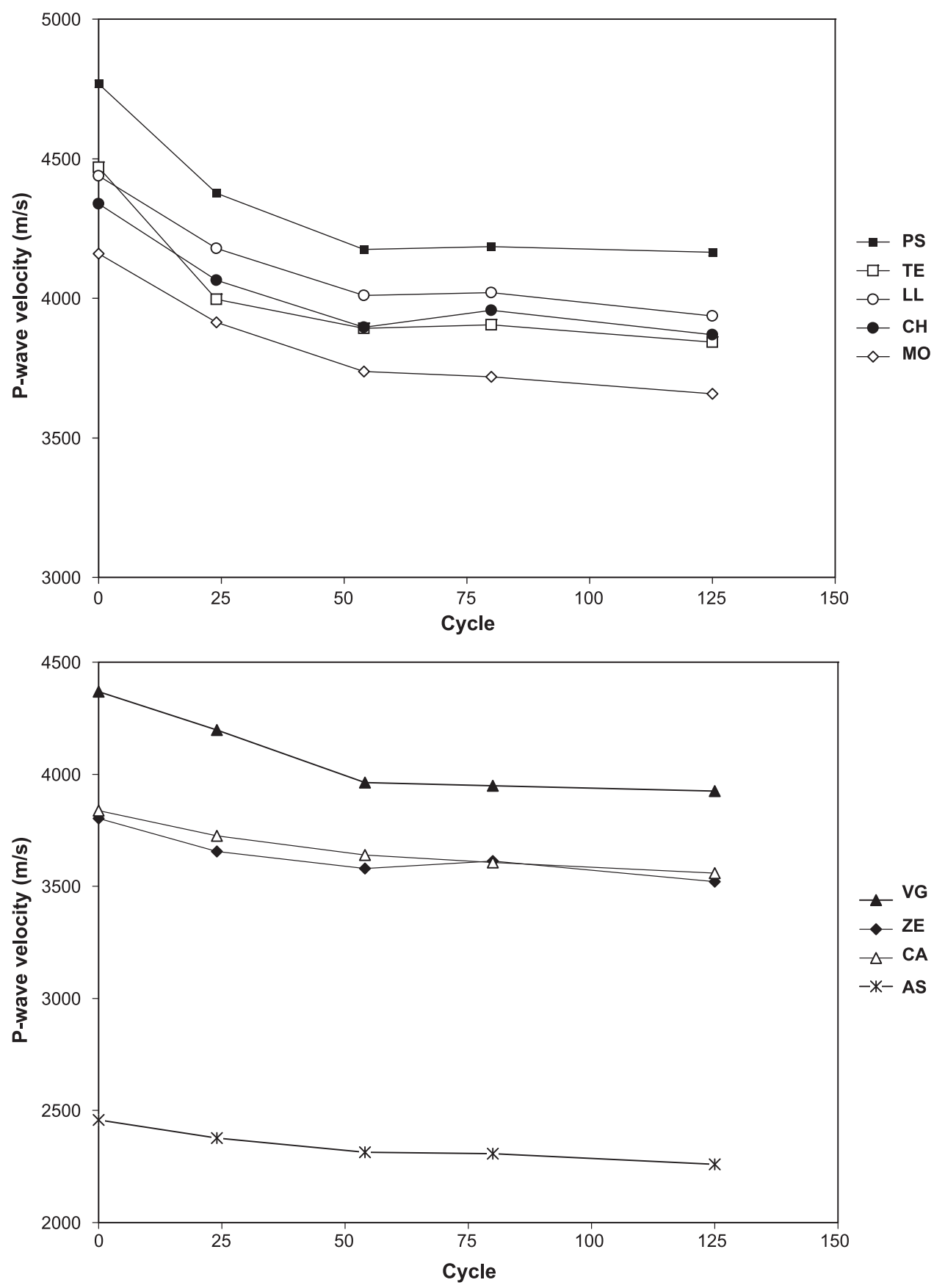

Fig. 11. P-wave velocity reduction during thermal shock testing (abbreviations can be found in Table 1).

pores and cracks makes the rock less continuous, thereby decreasing ultrasonic velocity and increasing breakability under compression.
Good correlation has been established between effective porosity and linear crack density, with the exception of the Águas Santas granite (Fig. 7). In this 


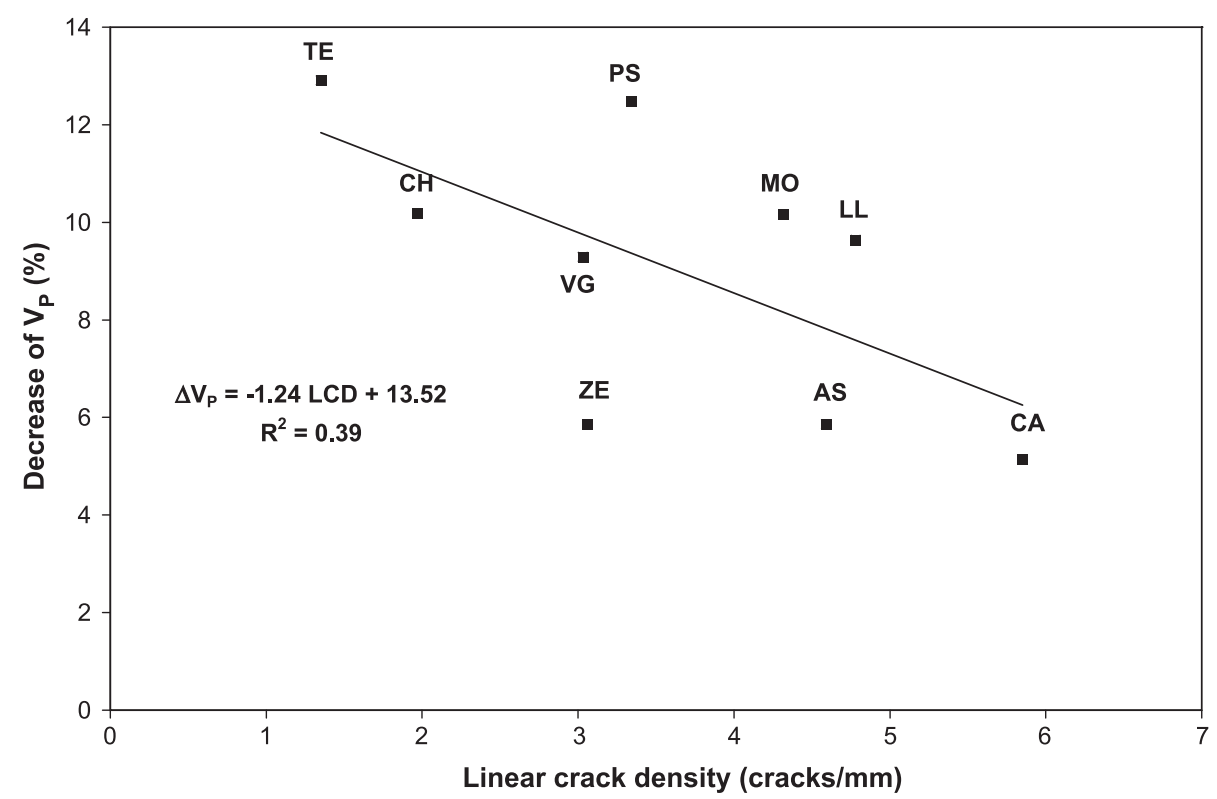

Fig. 12. Decrease of P-wave velocity $\left(\Delta V_{\mathrm{P}}\right)$ following thermal shock testing (125 cycles) and its relationship with LCD (abbreviations can be found in Table 1).

type of rock, the voids are predominantly microfractures; therefore, the direct relationship between effective porosity and microfracture content is deemed normal. Due to its high degree of weathering, the Águas Santas granite does not fit the trend line that the rest of the granites follow. In Figs. 8 and 9, the LCD is plotted against the uniaxial compressive strength and P-wave velocities, respectively. Although it would appear that there is an inverse correlation (as demonstrated by Richter and Simmons, 1977, and Wong et al., 1996), the determination coefficient $\left(R^{2}\right)$ is very low, which means that there are other factors affecting both properties. In the case of uniaxial compressive strength, texture (particularly grain size and the preferential orientation of some minerals) is a petrographic characteristic that influences the results (Suárez del Río, 1982). The P-wave velocity is also affected by the orientation of microfractures and minerals and by grain size (Suárez del Río, 1982). These characteristics have not been considered in this paper.

In the salt crystallization test, weight variations before and after the specimen washing is due to the removal of the salt deposited in the specimen voids and this difference will increase as the effective porosity increases (Fig. 10). The results obtained present a correlation between effective porosity, the amount of salt crystallized inside the specimens and the damage caused. These observed trends would corroborate in a more intelligible way if the granites under study had broader values of effective porosity.

The $V_{\mathrm{P}}$ decrease observed in thermal shock tests is also related to porosity and linear crack density; the more porous and highly cracked granites present lower variations and vice versa (Figs. 11 and 12). Weathered granites have some space that allows for mineral expansion and contraction; in the less weathered granites abrupt contraction leads to the formation of mainly intergranular cracks. However, the quality of the sound granites after thermal shock testing, evaluated in terms of P-wave velocity, is higher than that of granites already weathered prior to testing.

\section{Conclusions}

Most of the physical properties of granites destined for ornamental use are mainly influenced by the voids in the "intact rock". Inverse correla- 
tions between effective porosity and uniaxial compressive strength, as well as with P-wave velocity, have been established. Taking into account that the voids found in sound granites are largely microfractures, the same inverse correlations were expected between those properties and linear crack density. However, low correlation coefficients were obtained, which means that some other petrographical characteristics not considered in this paper, such as preferential crack and mineral orientation, grain size, etc., affected the results. Nonetheless, the trend in the relationship between these properties for sound granites changes as they become weathered. The good correlation obtained between effective porosity and linear crack density for sound or not highly weathered granites suggests that the microfracture width is more or less similar in these rocks. Weathering processes increase the width of microfractures and, hence, the amount of pore-shaped voids, particularly in feldspars, since the weathered granites do not follow the tendency of the sound ones. The different behavior observed in Águas Santas granite versus the other sound granites is striking. If the rocks had presented a homogeneous variation of effective porosity, the relationships detected would have been more intelligible.

The damage caused by the ageing tests (salt crystallization and thermal shock) is also conditioned by the voids. After 100 cycles of salt crystallization, granites with an effective porosity of less than $1.5 \%$ were practically unaffected and remained sound; however as porosity increases, material loss becomes more significant. In the thermal shock test, the generation of thermal cracks is greater in the first cycles and has a greater effect on those granites with low effective porosity, since the P-wave velocity decrease is more significant in those rocks. The volumetric expansion of minerals due to heating is "absorbed" by the microfractures in the granites with high porosity and fewer thermal cracks are produced than in the low porosity granites.

The physico-mechanical properties obtained for the granites under study lead us to conclude that all the granites studied are suitable for any application as dimension stones with the exception of Águas Santas granite, which is not suitable as ornamental rock, especially in outdoor applications, because of its high porosity and low durability.

\section{Acknowledgements}

To the "Ministerio de Ciencia y Tecnología" (Spain) (Project MAT2001-3594).

\section{References}

Almeida, L.C.R., Marques, E.A.G., Vargas Jr., E.A., Barros, W.T., 1998. Characterization and utilization of tensile strength and toughness of granitic and gneissic rocks of Rio de Janeiro City - a proposal for optimizing rock blasting processes. In: Moore, D.P, Hungr, O. (Eds.), Proc. 8th Int. Cong. of IAEG, vol. 1. Balkema, Vancouver, pp. 351-357.

Alonso, F.J., Ordaz, J., Valdeón, L., Esbert, R.M., 1987. Revisión crítica del ensayo de cristalización de sales. Mater. Constr. 206, $53-60$.

Al-Qudami, D., Shehata, W.M., Al-Harthi, A.A., Sabtan, A.A., 1997. On the weathering of syenite under arid conditions. Bull. IAEG 56, 3-8.

Álvarez-Calleja, A., Rodríguez-Rey, A., Montoto, M., Menéndez, B., Dubois, C., 1993. Cuantificación mediante estudio esterológico del sistema microfisural del granito de El Berrocal (Sistema Central Toledo, España). Acta Geol. Hisp. 28 (4), $63-69$.

Anonymous, 1995. The description and classification of weathered rocks for engineering purposes. Geological Society Engineering Group Working Party report. Q. J. Eng. Geol. 28, 207-242.

Aslam, M., 1992. Studies on conservation of marble in Agra monuments. In: Rodrigues, Delgado, et al., (Eds.), Proc. 7th Int. Cong. on Deterioration and Conservation of Stone, Lisbon, vol. 2, pp. 1507-1515.

Begonha, A.J.S., 1997. Meteorização do granito e deterioração da pedra em monumentos e edifícios da cidade do Porto, Tese de doutoramento. Universidade do Minho, Portugal.

Calleja, L., 1985. Variación de propiedades físicas en rocas sometidas a gradientes térmicos. Tesis Doctoral. Dpto. de Petrología, Fac. de Geología, Universidad de Oviedo, Spain, 252 pp.

Calleja, L., Montoto, M., Pérez García, B., Suárez del Río, L.M., Martínez Hernando, A., Menéndez Villar, B., 1989. An ultrasonic method to analyze the progress of weathering during cyclic salt crystallization laboratory tests. In: Zezza, Fulvio (Ed.), The Conservation of Monuments in the Mediterranean Basin. ISBN: 88-7385-060-X. pp. 313-318. Bari (Italy).

Clayton, J.L., Arnold, J.F., 1972. Practical grain size, fracturing density, and weathering classification of intrusive rocks of the Idaho batholit. U.S. Dept. Agriculture Forest Service Gen. Tech. Rept. INT-2, $17 \mathrm{p}$.

Davis, J.C., 1986. Statistics and Data Analysis in Geology. Jonh Wiley and Sons, New York.

Dearman, W.R., 1982. Selection of sandstone for architectural purposes. Proc. 4th Cong, IAEG, vol. 6, pp. 333-344.

Delgado Rodrigues, J., 1983. Laboratory study of thermally-fissured rocks. Memória, vol. 583. LNEC. 
Durgin, P.B., 1977. Landslides and the weathering of granitic rocks. Geological Society of America. Rev. Eng. Geol. 3, 127-131.

Ehlen, J., 2002. Some effects of weathering on joints in granitic rocks. Catena 49, 91-109.

Engelder, T., Plumb, R., 1984. Changes in in situ ultrasonic properties of rock on strain relaxation. Int. J. Rock Mech. Min. Sci. Geomech. Abstr. 21 (2), 75-82.

Eze, E.O., 1997. Geotechnical assessment of some charnockites from Nigeria as construction materials. Q. J. Eng. Geol. 30, 231-236.

Grossi, C.M., Esbert, R.M., Suárez del Río, L.M., Montoto, M., Laurenzi-Tabasso, M., 1997. Acoustic emission monitoring to study sulphate crystallisation in monumental porous carbonate stones. Stud. Conserv. 42, 115-125.

Gupta, A.S., Rao, K.S., 1998. Index properties of weathered rocks: inter-relationships and applicability. Bull. Eng. Geol. Environ. 57, $161-172$.

Gupta, A.S., Rao, K.S., 2000. Weathering effects on the strength and deformational behaviour of crystalline rocks under uniaxial compression state. Eng. Geol. 56, 257-274.

Gupta, A.S., Rao, K.S., 2001. Weathering indices and their applicability for crystalline rocks. Bull. Eng. Geol. Environ. 60, 201-221.

Halsey, D.P., Mitchell, D.J., Dews, S.J., 1998. Influence of climatically induced cycles in physical weathering. Q. J. Eng. Geol. 31, 359-367.

Hudec, P.P., 1998. Rock properties and physical processes of rapid weathering and deterioration. In: Moore, D.P., Hungr, O. (Eds.), Proc. 8th International Congress of IAEG, vol. 1. Balkema, pp. 335-341.

IAEG, 1981. Rock and soil descriptions for engineering geological mapping. Report by the IAEG Commission on Engineering Geological Mapping. Bull. Int. Assoc. Eng. Geol. 24, 235-274.

Ihalainen, P.E., Uusinoka, R.P.J., 1994. Comparison of weathering resistance of some building stones based on treatments simulating different external conditions. In: Oliveira, R., et al., (Eds.), Proc. 7th Inter. Cong. of IAEG, vol. 5. Balkema, Lisboa, pp. 3613-3618.

Irfan, T.Y., Dearman, W.R., 1978. The engineering petrography of a weathered granite in Cornwall, England. Q. J. Eng. Geol. 11, $233-244$.

ISRM, 1981a. Basic geotechnical description of rock masses. Int. J. Rock Mech. Min. Sci. Geomech. Abstr. 18, 85-110.

ISRM, 1981b. Rock characterization testing and monitoring. In: Brown, E.T. (Ed.), I.S.R.M. Suggested Methods.

Jermy, C.A., Bell, F.G., 1998. Durability of some dolerites from South Africa. In: Moore, D.P., Hungr, O. (Eds.), Proc. 8th Inter. Cong. of IAEG, vol. 4. Balkema, Vancouver, pp. 2869-2875.

Kelsall, P.C., Watters, R., Franzone, J.G., 1986. Engineering characterization of fissured, weathered dolerite and vesicular basalt. Proc. 27th U.S. Symposium, pp. 77-84.

Lan, H.X., Hu, R.L., Yue, Z.Q., Lee, C.F., Wang, S.J., 2003. Engineering and geological characteristics of granitic weathering profiles in South China. J. Asian Earth Sci. 21, $353-364$.

Marques, E.A.G., Vargas Jr., E.A., 1998. Geotechnical characterization of weathering profiles in biotite gneiss (kinzigites) from
Rio de Janeiro City. Mineralogical changes and physical properties. In: Moore, D.P., Hungr, O. (Eds.), Proc. 8th Int. Cong. of IAEG, vol. 4. Balkema, Vancouver, pp. 2673-2680.

Martin, L., Bello, M.A., Martin, A., 1992. Accelerated alteration tests on the stones used in the cathedral of Granada (Spain). In: Delgado Rodrigues, et al., (Eds.), Proc. 7th Int. Cong. on Deterioration and Conservation of Stone, Lisboa vol. 2, pp. $845-850$.

Martínez Hernando, A., Suárez del Río, L.M., 1989. Alterabilidad de algunos materiales graníticos de la Comunidad de Castilla y León utilizables como rocas ornamentales. Simposio sobre Rocas Industriales y Ornamentales, Mieres del Camino (Asturias-Spain), $11 \mathrm{pp}$.

McWilliams, J.R., 1966. The role of microstructure in the physical properties of rock. Testing techniques for rock mechanics. ASTM STP 402, 175-189.

Montoto, M., Rodríguez-Rey, A., Suárez del Río, L.M., Calleja, L., Ruiz de Argandoña, V.G., 1987. Methodology for microscopic studies of alteration of Building stones. In: E. Galán y M.A. Vázquez (Eds.), Sixth Meeting of the European Clay Groups, Euroclay' 87 (Round Table on: The Decay of Building Stone). Depósito legal: SE-921-87. pp. 45-48.

Montoto, M., Rodríguez-Rey, A., Menéndez, B., Martínez-Nistal, A., Ruiz de Argandoña, V.G., Suárez del Río, L.M., Calleja, L., 1994. Microfractography of "El Berrocal granite". In: Maravic, H., Smellie, J. (Eds.), Proceedings of an international workshop "Nuclear science and technology", pp. 353-358.

Neiva, J.M.C., Plasencia, N., Lima, C., 2000. Características geológico-geotécnicas do maciço rochosso do circuito hidráulico do empreendimento de Venda Nova II. Actas do VII Congr. Nac. Geotec. 1, 113-121.

Park, H.D., Kim, S.S., Chon, H.T., 1998. Durability of ornamental stone exposed to various weathering environments in Korea. In: Moore, D.P., Hungr, O. (Eds.), Proc. 8th International Congress of IAEG, vol. 4. Vancouver, Balkema, pp. 2953-2955.

Richter, D., Simmons, G., 1977. Microcracks in crustal igneous rocks: microscopy. In: Heacock, J.G. (Ed.), The Earth's crust: its nature and physical properties, Geophys. Serv. vol. 20, pp. 149-180.

RILEM, 1980. Essais recommandés pour mesurer l'altération des pierres et évaluer l'efficacité des méthodes de traitemente. Matér. Constr. 75, 175-253.

Rivas, T., Silva, B., Prieto, B., 1998. Medida de durabilidad de dos tratamientos de hidrofugación aplicados a rocas graníticas. Matér. Constr. 250, 5-14.

Roubault, M., 1963. Détermination des minéraux des roches au microscope polarisant. Lamarre-Poinat, Paris (France). 368 pp.

Ruiz de Argandoña, V.G., Calleja, L., Montoto, M., Suárez del Río, L.M., Rodríguez Rey, A., 1988. Petrophysical interpretation of the acoustic emission activity in heated crystalline rocks. Proc. 9th Int. Acoustic Emission Symp., Kobe (Japan), pp. $82-291$.

Schedl, A., Kronenberg, A.K., Tullis, J., 1986. Deformation microstructures of Barre granite: an optical SEM and TEM study. Tectonophysics $122,149-164$.

Serviços Geológicos of Portugal, 1992. Carta Geológica de Portugal. Scale 1:500000. 
Sousa, L.M.O., 2000. Estudo da fracturação e das características físico-mecânicas de granitos da região de Trás-os-Montes com vista à sua utilização como rocha ornamental. Tese de Doutoramento. Departamento de Geologia, Universidade de Trás-os-Montes e Alto Douro, Portugal. 358 pp.

Streckeisen, A., 1976. To each plutonic rock its proper name. Earth Sci. Rev. 12, 1-33.

Suárez del Río, L.M., 1982. Estudio petrofísico de materiales graníticos geomecánicamente diferentes. Tesis Doctoral. Departamento de Petrología, Universidad de Oviedo, Spain.

Suzuki, K., Oda, M., Kuwahara, T., Hirama, K., 1995. Material property changes in granitic rock during long term immersion in hot water. Eng. Geol. 40, 29-39.
Suzuki, K., Oda, M., Yamazaki, M., Kuwahara, T., 1998. Permeability changes in granite with crack growth during immersion in hot water. Int. J. Rock Mech. Min. Sci. Geomech. Abstr. 35 (7), 907-921

Tugrul, A., Zarif, I.H., 1999. Correlation of mineralogical and textural characteristics with engineering properties of selected granitic rocks from Turkey. Eng. Geol. 51, 303-317.

Wong, R.H.C., Chau, K.T., Wang, P., 1996. Microcracking and grain size effect in Yuen Long marbles. Int. J. Rock Mech. Min. Sci. Geomech. Abstr. 33 (5), 479-485. 